in the alloxan diabetes of the rabbits was investigated. Results obtained were as follows:

1) After alloxanization, the non-treatment group showed the specific fluctuation of 3 stages in blood sugar and alkaline phosphatase activity changes parallel as well.

2) The bilateral thyroidectomized group showed a little fluctuation of blood sugar and alkaline phosphatase activity respectively, and the continuous hyperglycemic stage did not appear in this group especially.

3) The bilateral adrenalectomized group did not show very clearly the initial stage in blood sugar, and immediately moved to the second stage, i.e., hypoglycemic stage and died by hypoglycemic shock within about $3 \mathrm{hrs}$. to $18 \mathrm{hrs.}$. But alkaline phosphatase activity was increased progressively.

4) The fluctuation of alkaline phosphatase activity in the alloxanization after the administration of the cortisone in the large dosage showed opposite on the initial and the second stage from the small dosage.

5) The castration group showed prolonged hypoglycemic stage and then the continuous hyperglycemic stage with increased alkaline phosphatase.

6) It was perhaps due to adrenal function that the fluctuations of blood sugar and alkaline phosphatase were observed at the initial stages of alloxan diabetes.

\title{
Studies of the D 860 Response Test in Diabetics
}

By

\section{N. SHIOZU, D. FUJITA, K. TANABE and T. NITTA}

IInd Internal Medicine, Kyoto Prefectural University of Medicine

The following results were attained by intravenous administration of $0.5 \mathrm{~g}$. D 860 in diabetics.

(1) In normal subjects, blood sugar level was decreased to the lowest, in average mean $43 \%$ reduction from the initial value in $30 \mathrm{~min}$. and restored to the intial level in $120 \mathrm{~min}$. . In diabetics, however the decreased rate in $30 \mathrm{~min}$. was $23 \%$ in effective cases of D 860 oral therapy, while only $10 \%$ in non-effective cases, and blood sugar level was shown the continuous slow decline without restoration until $120 \mathrm{~min}$.

(2) This D 860 response test therefore might be appriciable to differenciate between non diabetics, likeweise to predict the effectiveness of D 860 therapy per se.

(3) It was also found that the blood sugar curve following D 860 intravenous administration was quite similar that of insulin administration. This fact suggested that insulin would be released from Langerhans' island by D 860, however it was not negligible that extrapancreatic factors might be contributed to the mechanism of reduction of blood sugar level by this drug. 


\title{
糖尿病患者の D860 Response Test について
}

\author{
京都府立医科大学第二内科 \\ 塭 津 德 晃, 藤 田大 祐 \\ 田辺一夫，新田俊子
}

\section{はしがき}

糖尿病の治療に Sulfonyl 尿素剂が広く応用せられるようになつたが，揫知の如く木剂は個々の症例によ つて效果が一様でない.

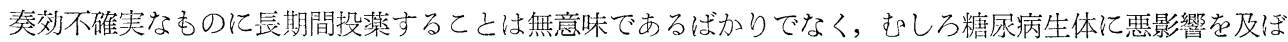
す恐れがあるから本剤使用洗だち，ま一゙適応を考虑することが必要である。

この目的で従来から多くの臨床家は患考の年令や体格などの Clinical Criteria を参考にしているが，乙

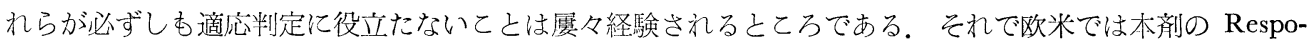

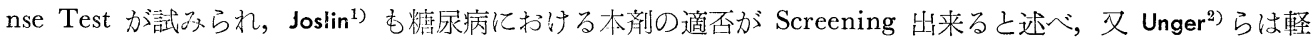
症糖尿病と非糖尿病の鑑別応用し得ると云つている。私たちも1956年来，D860 の静注法によりこれを行 つているので3)4)，いままでに得た知見をまとめて報告したいと思う。

\section{実 験 方 法}

当内科に入院した糖尿病㭧者について一定期間糖尿病食慨を拱らしめ，代謝状態が安定した後，早朝空腹 洔に10\% D860-Na水ソーダ溶淮 $5 \mathrm{cc}$ を肘静脈より徐々に注射し，15分，30分，60分及び 120分後に反対側の 静脈より採血して血糖量を測定した。すなうち，D860の注射量は体重に関係なく成人に対し一律に $500 \mathrm{mg}$ とした，次いで同一患者につき”D860の経口投与療法を行つて得た治療効果より有効，やや有効，無効の 3 群に分け，上記 Response Test の成績と比較検討した。 なお，D860の投与量は原則として第 1 日 $3 \mathrm{~g}$ ，第

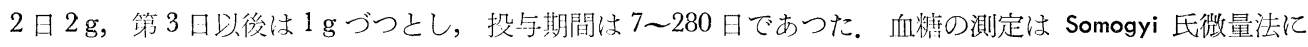
よつた.

\section{実 験 成 績}

\section{（1）韭糖尿病群の D860 静注試験}

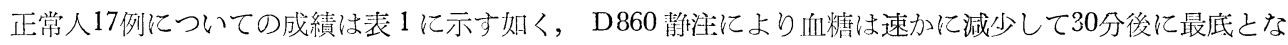
りその減少率は平均43\%を示した。次いで恢復して60分後には平均15\%となり，120分で実験前値に復した。

\section{(2) 糖尿病患者の D860 静注試験}

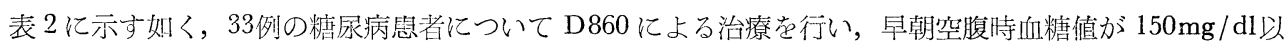
下，1 日尿糖量 $10 \mathrm{~g}$ 以内之なつたものを有効群とし，血糖佔が $150 \sim 200 \mathrm{mg} / \mathrm{dl}$, 尿糖量 1 日 10 20gのもの, 又は初めインショリンにて Control した後D860亿罱換し得たあのをやや有効群，その他を無効群とし，乙 れら 3 群における治療前の D860 Response Test の成績を述べると次の如くである.

まづ有効群18例においては表 $3 \mathrm{~A}$ 亿示す如く，負荷前血煻值は平均 $208 \mathrm{mg} / \mathrm{dl}$ で，30分後には平均 160 $\mathrm{mg} / \mathrm{dl}$ となり，その減少率は平均 $23 \%$ で，非糖尿病群の $43 \%$ に比べると減少が著しく軽度である。 その後 は非糖尿病群の如く恢復するととなく漸次減少して 120 分後には平均 $41 \%$ を示した。

やや有效群 8 例では表 $3 \mathrm{~B}$ の如く, 血糖の減少は有効群より整度であつた。

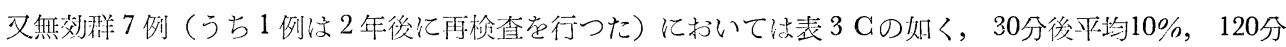


表 1 正常人の D 860 静注試験

\begin{tabular}{|c|c|c|c|c|c|c|c|c|}
\hline \multirow{2}{*}{$\frac{\text { 症 }}{\text { 坂 } 0}$} & \multirow{2}{*}{$\frac{\text { 例 }}{18 才 \hat{。}}$} & \multirow{2}{*}{$\frac{\begin{array}{c}\text { 負荷前血糖 } \\
\mathrm{mg} / \mathrm{dl}\end{array}}{78}$} & \multicolumn{2}{|c|}{$\begin{array}{c}15 \text { 分後血糖 } \\
\mathrm{mg} / \mathrm{dl}(\text { 減少\%) }\end{array}$} & \multicolumn{2}{|c|}{$\begin{array}{c}30 \text { 分後血糖 } \\
\mathrm{mg} / \mathrm{dl}(\text { 減少 } \%)\end{array}$} & $\begin{array}{c}60 \text { 分後血糖 } \\
\mathrm{mg} / \mathrm{dl}(\text { 減少 } \%)\end{array}$ & $\begin{array}{c}120 \text { 分後血糖 } \\
\mathrm{mg} / \mathrm{dl}(\text { 減少\%) }\end{array}$ \\
\hline & & & 48 & (39) & 30 & (62) & $76 \quad(3)$ & (13) \\
\hline 有 $\bigcirc$ & 18才우 & 81 & 66 & (18) & 34 & (58) & (15) & (11) \\
\hline 辻 0 & $60 才 \hat{~}$ & 86 & 53 & (39) & 37 & (57) & $(20)$ & (10) \\
\hline 西 $\bigcirc$ & 27才우 & 91 & 71 & (22) & 53 & (42) & $(21)$ & (10) \\
\hline 原 $\bigcirc$ & 35才우 & 69 & 52 & (24) & 40 & (42) & (13) & $(0)$ \\
\hline 横 $\bigcirc$ & 24才우 & 81 & 60 & (26) & 48 & (41) & (31) & $(22)$ \\
\hline 橋 $\bigcirc$ & $35 才 \hat{o}$ & 67 & 62 & (7) & 42 & (37) & $(7)$ & $72(+7)$ \\
\hline 筧 $\bigcirc$ & $26 才 \hat{。}$ & 78 & 60 & (24) & 50 & (36) & (14) & $78 \quad(0)$ \\
\hline 紀 $\bigcirc$ & $48 才 \hat{。}$ & 74 & 53 & (19) & 37 & (33) & (8) & $(4)$ \\
\hline 池 $\bigcirc$ & $20 才 \hat{\delta}$ & 85 & 76 & (10) & 63 & (26) & (5) & $(0)$ \\
\hline 飯 $\bigcirc$ & $30 才 \hat{\delta}$ & 88 & 29 & (67) & 34 & (61) & (26) & (6) \\
\hline 増 $\bigcirc$ & 56才令 & 115 & 111 & (3) & 90 & (22) & $75 \quad(25)$ & (28) \\
\hline 徳 $\bigcirc$ & 24才令 & 62 & 46 & (26) & 28 & (55) & $73(+18)$ & $58 \quad(6)$ \\
\hline 船 $\bigcirc$ & 56才令 & 81 & 69 & (15) & 59 & (27) & $76 \quad(6)$ & $89(+10)$ \\
\hline 福 $\bigcirc$ & $29 才 \hat{。}$ & 68 & 62 & (9) & 42 & (38) & $(9)$ & $79(+16)$ \\
\hline 中 0 & 65才令 & 80 & 48 & (40) & 44 & (45) & $23 \quad(78)$ & $74 \quad(8)$ \\
\hline 永 $\bigcirc$ & 20才令 & 80 & 35 & (56) & 48 & $(40)$ & $102(+28)$ & $118(+48)$ \\
\hline 平 & 均 & 80 & 59 & (26) & 46 & (43) & $(15)$ & $(1)$ \\
\hline
\end{tabular}

後平均 $20 \%$ の減少率を示し，前 2 群より更に低値であつた。

上述の成績を一括すると図 1 亿示す如く，D 860 静注 30 分後の血糖減少率は非糖尿病群では概祙 $25 \%$ 以上 であるが，糖尿病群ではこれより少く，120 分後においてはてれに反し非糖尿病群が $15 \%$ 以内にまで恢復す るにかかわらず，糖尿病群では恢復を示さない。すなわち，30分及び 120 分後の血糖減少率によつて非糖尿 病と糖尿病を区別するととが出来た。

又糖尿病では図 2 亿示す如く，D860 亿よる治療が有效又は無効の両群の間に血糖減少率に堅異を認め， 子め Response Test を行うことによつて木郕適否の判定に応用するととが出来る。

\section{(3) インシュリン静注試験}

D 860 Response Test を行つた糖尿病㥯者について，インシュリン $0.1 \mathrm{u} / \mathrm{kg}$ を责静注し，血糖の変化をし らべたところ, 表 4 の如くD860有效群17例ではインシュリン注射後著しく隇少して60分後最む低佰となり, 平均 $54 \%$ の減少率を示し，120分後には平均44\%に恢復した。

無効群 7 例に未ける血糖の減少は餐度で，60分後平均 $26 \%, 120$ 分後平均 $30 \%$ を示し，又やや有効群 8 例で はこれら両群の中間の値を示した。

上述の成績は図 3 亿示す如くで，D 860 有效群は無效群よりインシュリン注射後の血糖降下が渚しく，乙 れを図 2 における D 860 静注陚験と比較すると両者の血糖下降曲線は互に近似するととを認めた。

\section{総括及び考案}

正常人に D860 500 mg を静注すると血糖は30分後平均43\%減少して最低となり，120分後には注射前値 に復したが，糖尿病㭧者では減少が軽度で 120 分に至るまで減少を続けた。乙れらの糖尿病恵者をD860が 奏效したものと，やや有效及び無効の 3 群に分け，上述の静注試験の成績を検討寸ると，注射30分後におけ る減少率はそれぞれ平均23\%，11\%及び10\%で，3 群の間に差異のあるととを認めた。 
表 2 楉 疛 病患者一覧 表

\begin{tabular}{|c|c|c|c|c|c|c|c|c|}
\hline 症 & 例 & $\mid$\begin{tabular}{c|} 
D860 治療 \\
前血糖 $\mathrm{mg} / \mathrm{dl}$
\end{tabular} & $\mid \begin{array}{c}\mathrm{D} 860 \text { 治療 } \\
\text { 後血糖 } \mathrm{mg} / \mathrm{dl} \mid\end{array}$ & $\left|\begin{array}{c}\text { D860 治寮 } \\
\text { 前尿糖 } \mathrm{g} / \text { day }\end{array}\right|$ & $\mid \begin{array}{c}\text { D860 治療 } \\
\text { 後尿糖 } \mathrm{g} / \mathrm{day}\end{array}$ & 投与日数 & 效 & 果 \\
\hline 園○ & 51才早 & 248 & 140 & 24 & 0 & 22 & 有 & 効 \\
\hline 東 ○ & 42 才令 & 215 & 150 & 14 & 0 & 25 & \multicolumn{2}{|c|}{ "I } \\
\hline 高 0 & 50才우 & 195 & 92 & 50 & 0 & 14 & \multicolumn{2}{|r|}{ " } \\
\hline 谷 $\bigcirc$ & $49 才 \hat{~}$ & 178 & 140 & 20 & 0 & 62 & \multicolumn{2}{|r|}{11} \\
\hline 北 0 & 65才우 & 203 & 90 & 60 & 0 & 60 & \multicolumn{2}{|r|}{ "I } \\
\hline 住 ○ & $52 才 \preccurlyeq$ & 160 & 97 & 25 & 0 & 30 & \multicolumn{2}{|r|}{ "I } \\
\hline 物 ○ & $58 才 \hat{。}$ & 282 & 99 & 20 & 0 & 45 & \multicolumn{2}{|r|}{ "I } \\
\hline 中 0 & 64才우 & 187 & 127 & 59 & 0 & 34 & \multicolumn{2}{|r|}{ "I } \\
\hline 閣 & 55才里 & 193 & 77 & 63 & 0 & 30 & \multicolumn{2}{|r|}{ "I } \\
\hline 大 0 & 48才우 & 201 & 120 & 30 & 0 & 10 & \multicolumn{2}{|r|}{ "I } \\
\hline 岩 $\bigcirc$ & 49才令 & 188 & 93 & 50 & 0 & 90 & \multicolumn{2}{|r|}{ "I } \\
\hline 江 0 & 23才우 & 228 & 80 & 53 & 0 & 9 & \multicolumn{2}{|r|}{ "I } \\
\hline 根 ○ & 50才우 & 210 & 148 & 15 & 0 & 80 & \multicolumn{2}{|r|}{ "I } \\
\hline 尾 ○ & 62才우 & 170 & 125 & 60 & 0 & 13 & \multicolumn{2}{|r|}{ "I } \\
\hline 細 ○ & 66才우 & 220 & 110 & 13 & 5 & 10 & \multicolumn{2}{|r|}{ "I } \\
\hline 加 $\bigcirc$ & 56才우 & 267 & 130 & 82 & 5 & 30 & \multicolumn{2}{|r|}{ "I } \\
\hline 吉 $\bigcirc$ & $61 才 \hat{\delta}$ & 191 & 122 & 50 & 10 & 10 & \multicolumn{2}{|r|}{ "I } \\
\hline 加 $\bigcirc$ & 42 才令 & 197 & 122 & 44 & 10 & 10 & \multicolumn{2}{|r|}{ "1 } \\
\hline 村 $\bigcirc$ & 49才우 & 368 & 188 & 120 & 0 & 27 & \multirow{8}{*}{\multicolumn{2}{|c|}{ 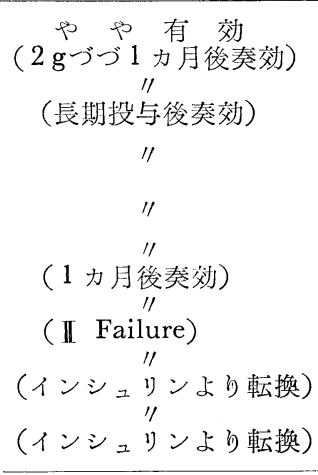 }} \\
\hline 佐 $\bigcirc$ & 47才우 & 207 & 188 & 100 & 20 & 240 & & \\
\hline 谷 $\bigcirc$ & $61 才 \hat{。}$ & 250 & 150 & 20 & 0 & 43 & & \\
\hline 上 0 & 79才今 & 271 & 156 & 80 & 20 & 30 & & \\
\hline 川 & 21才우 & 375 & 192 & 75 & 20 & 60 & & \\
\hline 田 $\bigcirc$ & 20 才우 & 258 & 223 & 70 & 20 & 240 & & \\
\hline 中 0 & $44 才 \hat{0}$ & 197 & 161 & 120 & 8 & 10 & & \\
\hline 仲 & & 382 & 151 & 120 & 0 & 10 & & \\
\hline 石 $\bigcirc$ & 19才令 & 383 & 277 & 400 & 260 & 26 & \multirow{7}{*}{\multicolumn{2}{|c|}{$\begin{array}{c}\text { 無 } \\
\text { 効 } \\
\text { " } \\
\text { " } \\
\text { " } \\
\text { " } \\
\text { " }\end{array}$}} \\
\hline 石（2 & 2 年後) & 250 & 217 & 86 & 55 & 7 & & \\
\hline 内 0 & $29 才 \hat{。}$ & 277 & 185 & 480 & 160 & 140 & & \\
\hline 过 0 & 56才㝵 & 278 & 257 & 70 & 70 & 80 & & \\
\hline 福 $\bigcirc$ & 44才우 & 334 & 259 & 70 & 100 & 60 & & \\
\hline 北 $\bigcirc$ & 53才令 & 259 & 238 & 100 & 100 & 60 & & \\
\hline 片 $\bigcirc$ & 46才㝵 & 275 & 266 & 77 & 60 & 12 & & \\
\hline
\end{tabular}

このように D860 Response Test によつて，注射30分後の血糖減少率及び 120 分までの血糖下降曲線か

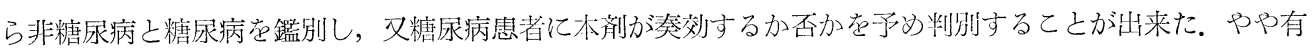
效群は両者の中間の值を示し，本剤の適応を予測することが困難であつたが，それらの症例の中には患者中

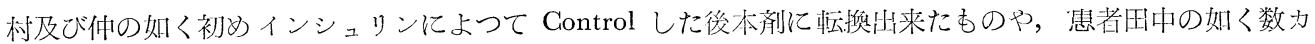


表 3 糖尿病息者の D860 静注武䍄

(A) D860 有効群

\begin{tabular}{|c|c|c|c|c|c|c|c|c|c|c|}
\hline 症 & 例 & $\begin{array}{c}\text { 負荷前血糖 } \\
\mathrm{mg} / \mathrm{dl}\end{array}$ & \multicolumn{2}{|c|}{$\begin{array}{c}\text { 15分後血糖 } \\
\mathrm{mg} / \mathrm{dl}(\text { 減少 } \%)\end{array}$} & \multicolumn{2}{|c|}{$\begin{array}{c}30 \text { 分後血糖 } \\
\mathrm{mg} / \mathrm{dl}(\text { 減少 } \%)\end{array}$} & \multicolumn{2}{|c|}{$\begin{array}{c}\text { 60分後血糖 } \\
\mathrm{mg} / \mathrm{dl}(\text { 減少 } \%)\end{array}$} & \multicolumn{2}{|c|}{$\begin{array}{c}120 \text { 分後血糖 } \\
\mathrm{mg} / \mathrm{dl}(\text { 減少 } \%)\end{array}$} \\
\hline 園 & 0 & 229 & 187 & (18) & 175 & (24) & 170 & (26) & 158 & (31) \\
\hline 東 & 0 & 215 & 180 & (16) & 140 & (35) & 145 & (33) & 157 & (27) \\
\hline 高 & 0 & 195 & 183 & (6) & 120 & (38) & 108 & (45) & 85 & (56) \\
\hline 谷 & 0 & 178 & 161 & (10) & 152 & (15) & 148 & (17) & 135 & (24) \\
\hline 北 & 0 & 203 & 204 & $(0)$ & 182 & (11) & 113 & (44) & & \\
\hline 住 & 0 & 160 & 157 & (2) & 120 & (25) & 130 & (19) & 98 & (38) \\
\hline 物 & 0 & 282 & 199 & $(29)$ & 180 & (36) & 220 & (22) & 145 & (49) \\
\hline 中 & 0 & 187 & 200 & $(+7)$ & 159 & (15) & 153 & (18) & 107 & (43) \\
\hline 閣 & & 193 & 172 & (12) & 175 & (11) & 152 & (22) & 140 & (27) \\
\hline 大 & 0 & 201 & 183 & $(9)$ & 159 & (21) & 136 & (32) & 103 & (24) \\
\hline 岩 & 0 & 188 & 185 & $(0)$ & 167 & (11) & 142 & (24) & 118 & (37) \\
\hline 江 & 0 & 228 & 228 & $(0)$ & 210 & (8) & 188 & (17) & 141 & (38) \\
\hline 根 & 0 & 182 & 163 & (10) & 148 & (19) & 124 & (32) & 109 & $(40)$ \\
\hline 尾 & 0 & 170 & 134 & (21) & 145 & (15) & 110 & (35) & 103 & (38) \\
\hline 紐 & 0 & 220 & 123 & (14) & 144 & (35) & 118 & (46) & 108 & (51) \\
\hline 加 & 0 & 314 & 270 & (14) & 235 & (25) & 214 & (32) & 158 & (50) \\
\hline 吉 & 0 & 191 & 156 & (18) & 145 & (24) & 179 & (6) & 161 & (16) \\
\hline 加 & 0 & 212 & 128 & $(40)$ & 125 & $(41)$ & 101 & (52) & 73 & (66) \\
\hline 平 & 均 & 208 & 179 & (14) & 160 & (23) & 147 & (29) & 123 & (41) \\
\hline
\end{tabular}

(B) D860 やや有効群

\begin{tabular}{|c|c|c|c|c|c|c|c|c|c|}
\hline 村 $\bigcirc$ & 368 & 339 & (8) & 330 & (10) & 323 & (12) & 295 & (20) \\
\hline 佐 $\bigcirc$ & 187 & 169 & (10) & 163 & (13) & 158 & (16) & 138 & (26) \\
\hline 谷 $\bigcirc$ & 252 & 240 & (3) & 235 & (5) & 230 & (7) & 208 & (19) \\
\hline 上久 0 & 271 & 263 & (3) & 263 & (3) & 238 & (12) & 197 & (26) \\
\hline 川 & 357 & 339 & (5) & 317 & (11) & 275 & (22) & 245 & (31) \\
\hline 田 ○ & 328 & 308 & (6) & 292 & (11) & 259 & (22) & 120 & (63) \\
\hline 中 $\bigcirc$ & 314 & 279 & (11) & 268 & (15) & 253 & (19) & 232 & (26) \\
\hline 仲 & 433 & 325 & (25) & 362 & (16) & 333 & (23) & 251 & (42) \\
\hline 均 & 314 & 283 & (10) & 279 & (11) & 259 & (18) & 211 & (33) \\
\hline
\end{tabular}

(C) D860 無効群

\begin{tabular}{ll|l|ll|ll|ll|ll}
\hline 石 & $\bigcirc$ & 261 & 255 & $(2)$ & 246 & $(6)$ & 242 & $(7)$ & 203 & $(22)$ \\
石 & $\bigcirc$ & 176 & 133 & $(24)$ & 154 & $(13)$ & 141 & $(20)$ & 141 & $(20)$ \\
内 & 0 & 282 & 280 & $(1)$ & 270 & $(5)$ & 263 & $(7)$ & 254 & $(10)$ \\
过 & & 278 & 270 & $(3)$ & 259 & $(7)$ & 258 & $(8)$ & 217 & $(22)$ \\
福 & 0 & 334 & 291 & $(13)$ & 287 & $(14)$ & 259 & $(22)$ & 228 & $(32)$ \\
北 & $\bigcirc$ & 259 & 256 & $(1)$ & 256 & $(1)$ & 226 & $(13)$ & 211 & $(19)$ \\
片 & $\bigcirc$ & 290 & 245 & $(16)$ & 217 & $(25)$ & 220 & $(24)$ & 245 & $(16)$ \\
\hline 平 & 均 & 269 & 247 & $(8)$ & 241 & $(10)$ & 230 & $(15)$ & 214 & $(20)$ \\
\hline
\end{tabular}


表 4 粘尿病㭧者のインシュリン静注試験

(A) D860 有效群:

\begin{tabular}{|c|c|c|c|c|c|c|c|c|c|c|}
\hline \multirow{2}{*}{ 症 } & \multirow{2}{*}{ 例 } & \multirow{2}{*}{$\frac{\begin{array}{c}\text { 注 射 前 血 糖 } \\
\mathrm{mg} / \mathrm{dl}\end{array}}{298}$} & \multicolumn{2}{|c|}{$\begin{array}{c}15 \text { 分後血糖 } \\
\mathrm{mg} / \mathrm{dl}(\text { 減少\%) }\end{array}$} & \multicolumn{2}{|c|}{$\begin{array}{c}30 \text { 分後血糖 } \\
\mathrm{mg} / \mathrm{dl}(\text { 隇少 } \%)\end{array}$} & \multicolumn{2}{|c|}{$\begin{array}{c}\text { 60分後血糖 } \\
\mathrm{mg} / \mathrm{dl}(\text { 減少\%) }\end{array}$} & \multicolumn{2}{|c|}{$\begin{array}{c}120 \text { 分後血䊞 } \\
\mathrm{mg} / \mathrm{dl}(\text { 娍少 } \%)\end{array}$} \\
\hline & & & 180 & $(40)$ & 109 & (63) & 120 & $(60)$ & 141 & (53) \\
\hline 笨 & 0 & 176 & 87 & (51) & 75 & $(57)$ & 86 & (51) & 95 & (46) \\
\hline 高 & 0 & 170 & 45 & (74) & 56 & (68) & 62 & (64) & 83 & (51) \\
\hline 谷 & 0 & 194 & 142 & $(27)$ & 120 & (38) & 115 & (41) & 135 & (30) \\
\hline 北 & 0 & 185 & 171 & (8) & 123 & (39) & 86 & (53) & 127 & (31) \\
\hline 住 & 0 & 150 & 107 & (29) & 85 & (43) & 117 & (22) & 141 & (6) \\
\hline 物 & 0 & 175 & 104 & (41) & 60 & (66) & 65 & (63) & 80 & (54) \\
\hline 中 & $\mathrm{O}$ & 198 & 163 & (18) & 145 & (27) & 122 & (38) & 135 & $(32)$ \\
\hline 药 & & 185 & 145 & (21) & 132 & (29) & 118 & $(36)$ & 133 & (28) \\
\hline 大 & 0 & 167 & 121 & (28) & 128 & (23) & 86 & $(48)$ & 113 & $(32)$ \\
\hline 岩 & 0 & 159 & 77 & (51) & 57 & $(64)$ & 13 & (92) & 31 & $(80)$ \\
\hline 江 & 0 & 221 & 185 & (16) & 103 & (53) & 105 & (52) & 139 & $(37)$ \\
\hline 根 & O & 190 & 166 & (13) & 130 & (32) & 108 & (43) & 148 & $(22)$ \\
\hline 紐 & $\mathrm{O}$ & 197 & 121 & $(39)$ & 121 & (39) & 74 & (63) & 98 & (50) \\
\hline 加 & 0 & 250 & 170 & (32) & 144 & $(42)$ & 110 & $(56)$ & 86 & (64) \\
\hline 吉 & $\bigcirc$ & 191 & 123 & (36) & 102 & (47) & 48 & $(75)$ & 88 & (54) \\
\hline 加 & 0 & 128 & 80 & (38) & 48 & (63) & 44 & $(66)$ & 44 & (66) \\
\hline 平 & 均 & 190 & 129 & (32) & 102 & $(46)$ & 87 & (54) & 107 & $(44)$ \\
\hline
\end{tabular}

（B） D860 やや有効群

\begin{tabular}{|c|c|c|c|c|c|c|c|c|c|}
\hline 村 $\bigcirc$ & 455 & 375 & (18) & 353 & (23) & 330 & (28) & 323 & (29) \\
\hline 佐 $\bigcirc$ & 328 & 281 & (14) & 273 & (17) & 260 & (21) & 245 & (25) \\
\hline 谷 0 & 248 & 240 & (3) & 227 & (8) & 146 & (41) & 188 & (24) \\
\hline 上久 $\bigcirc$ & 241 & 224 & (7) & 156 & (35) & 167 & (31) & 150 & (38) \\
\hline$川 0$ & 396 & 322 & (19) & 268 & (32) & 246 & (38) & 241 & (39) \\
\hline 由 0 & 384 & 317 & (19) & 242 & (37) & 226 & (40) & 233 & (39) \\
\hline 中 $O$ & 197 & 185 & (6) & & & 129 & (35) & 153 & (22) \\
\hline 仲 & 329 & 249 & (24) & 245 & (22) & 228 & (31) & 204 & (38) \\
\hline 均 & 322 & 274 & (15) & 252 & (22) & 217 & (32) & 217 & (33) \\
\hline
\end{tabular}

(C) D860 無効群

\begin{tabular}{ll|l|ll|ll|ll|ll}
\hline 石 & 0 & 442 & 390 & $(12)$ & 340 & $(23)$ & 321 & $(27)$ & 295 & $(33)$ \\
石 & $\bigcirc$ & 191 & 161 & $(16)$ & 141 & $(26)$ & 147 & $(23)$ & 141 & $(26)$ \\
内 & $\bigcirc$ & 282 & 228 & $(16)$ & 196 & $(31)$ & 173 & $(39)$ & 121 & $(57)$ \\
辻 & & 330 & 284 & $(14)$ & 256 & $(22)$ & 252 & $(24)$ & 238 & $(28)$ \\
福 & $\bigcirc$ & 295 & 291 & $(1)$ & 267 & $(10)$ & 204 & $(31)$ & 210 & $(29)$ \\
北 & $\bigcirc$ & 275 & 278 & $(+1)$ & 245 & $(11)$ & 227 & $(17)$ & 217 & $(21)$ \\
片 & ○ & 290 & 245 & $(16)$ & 217 & $(25)$ & 220 & $(24)$ & 245 & $(16)$ \\
\hline 平 & 均 & 300 & 268 & $(11)$ & 237 & $(21)$ & 221 & $(26)$ & 210 & $(30)$ \\
\hline
\end{tabular}


図 1 D860 Response Test $\left(\begin{array}{l}\circ \text { nondiabetic } \\ \bullet \text { diabetic }\end{array}\right)$

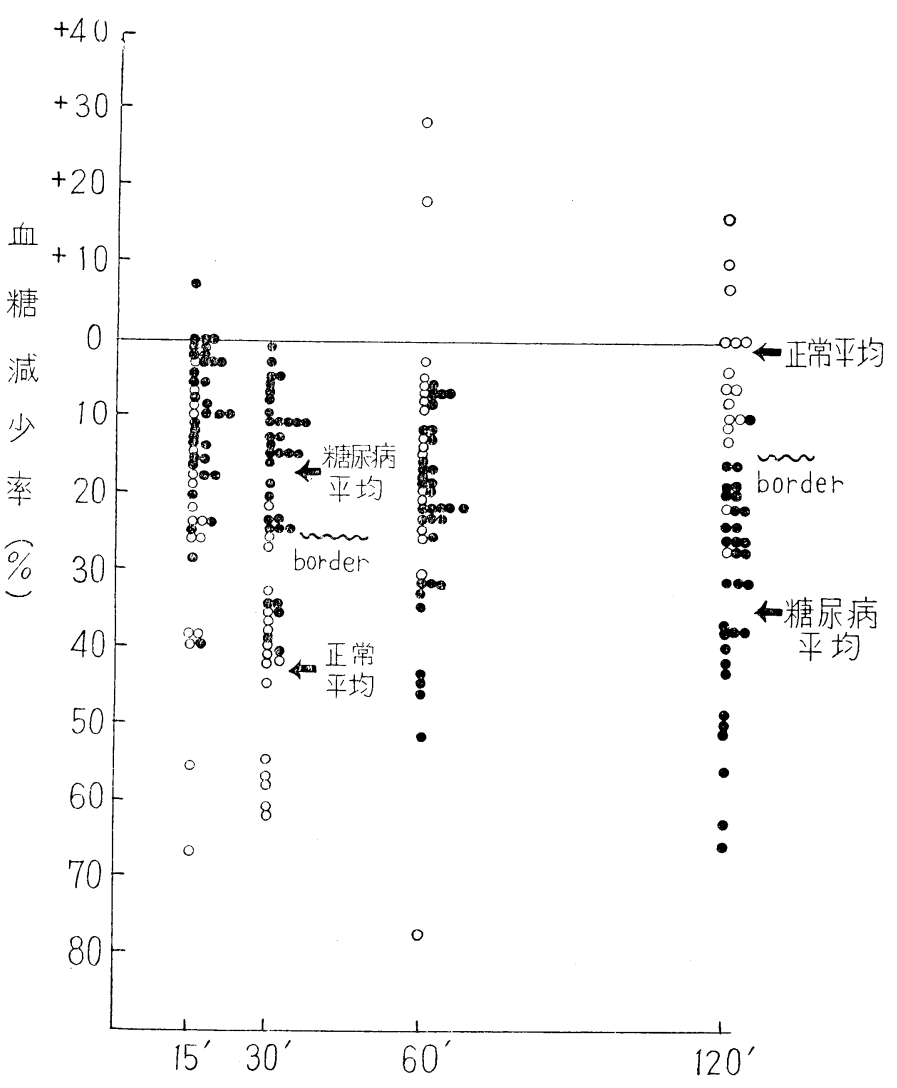

図 2 糖尿病恵者の D860 Test

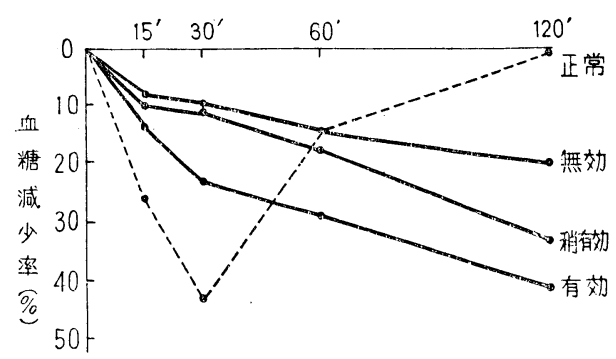

図 3 糖尿病患者の Insulin Test

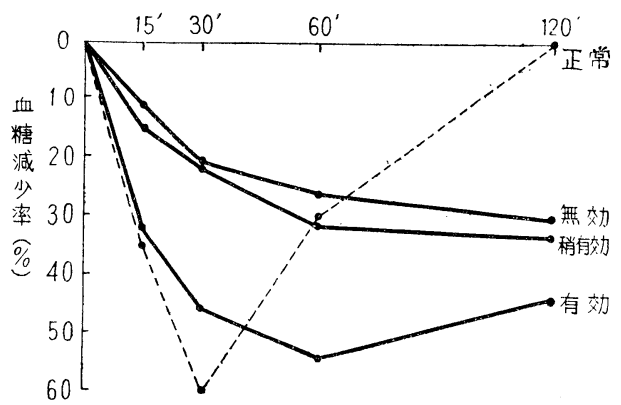

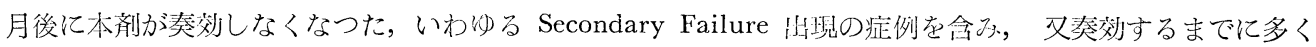
の日数を要したもの，或は投与量を增加して効畏を認めた症例屯あつた。

本剂適応の基準として従来から発病年令，体梨，インシュリン使用歴などが参考とせられているが，必ず

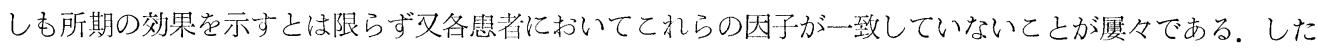


がつて一定期間投薬した後, 適否が判定せられている現状である。しかしながら無郊の症例（primary Failure）に対し本剤を投薬することは無意味であるばかりでなく, Pfeiffer ${ }^{5)}$ あ述べる如く長期間の投与は煻尿 病患者のラ氏島 $\beta$ 細胞を疲德せしめるおそれがあるから，投薬前に子め Screening を行い適否を判定する 乙とは有意義と考光る。

このため欧米においては諸家により Response Test が試みられ，たとえば Camerini-Davalos ${ }^{6}$ らは D860, $3 \mathrm{~g}$ の経口投与を行い，4 時間後の血糖減少率が $20 \%$ 以を示した糖尿病群では，そのうち $87 \%$ の症例にD 860 が奏效し，20\%以下の血糖娍少率のあのはすべて無效であつたといい，予め Test を行うことは本郕匛 用の適否判定に役立つ之述べている.

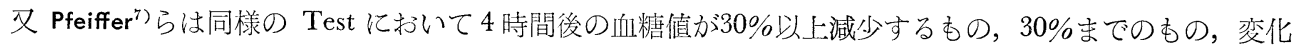
なきか増加するものの 3 群に分け，第 1 群は26例中 21 例，第 2 群は25例中 6 例において D860 が奏効した が，第 3 群の 9 例はすべて無効であつたという.

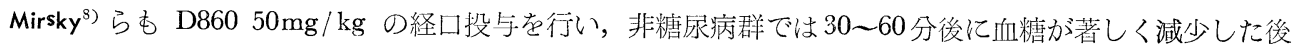
漸次恢復するが，糖尿病では 5 時間後まで徐々に減少するD860 Responsive group と，減少を示さない Nonresponsive group のあることを認めている.

てのように糖尿病では D 860 Response Test 亿おいて特異な血糖曲線を示すととを私達む認めたが，そ の機序については一致した見解がない，Mirsky $\left.{ }^{8}\right)$ らよると糖尿病においては Wrenshal \& Best ${ }^{9}$ の述べる 如きラ氏島インシュリンの減少によりD860 投与後のインシュリン放出量が少く，従つて血糖の減少は軽度 であり，他方末佾では D 860 亿よるインシュリナーゼ活性阻害によつて血糖減少か持続すると説明し，又乙 のように糖尿病で血糖下降が徐々に発現することについて Pfeiffer ${ }^{7) 10}$ はラ氏島組織所見からD860 による $\beta$ 細胞のインシュリン库生が緩徐に起るためであると述べている。

上述諸家の負荷陚験は経口法であるが，Bravermann ${ }^{11)}$, Unger $^{12}$ )，Kinsel1 $\left.{ }^{13}\right)$ らは私達と同じく静注法によつ ている。即ち，Bravermann は D860，1g t在静注し，非糖尿病では30分後に血糖が平均 $37 \%$ 減少し， 2 時間 後には負荷前值に復するが，糖症病では徐々に減少して恢復することなく，关のうち 30 分後の血糖が平均 26 \%の減少を示す D 860 有效群と，7\%を示す無効群を区別することが出来ると述心，私達の成績とほぼ一致 する.

Unger らは同様の検査において 30 分後に試験前值の77\%まで減少するか否かにより非糖尿病と糖尿病を鑑 別出来ると述べている。

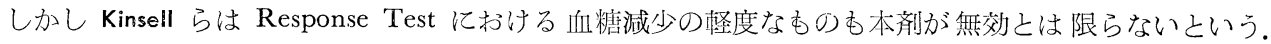

又 Response Test の判定基準として Mehnert ${ }^{14)}$ ，Joslin ${ }^{1}$ らは D $8603 \mathrm{~g}$ の経口投与法により，4 時間後 に正常血糖值上界（100～ $110 \mathrm{mg} / \mathrm{dl}$ ) まで娍少するや否やによつてD860の適応を判定出来ると述へている。

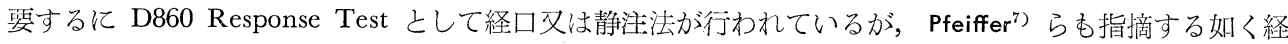
口法は腸より吸収の影響を考慮する必要があり，又血糖の迅速なる変動を知るためには静注法が優れている と云えよう.

判定方法としては15〜30分の短時間内検査では血糖減少率を基準とし，2４ 時間の観察ならば血糖曲線 を検討することが非糖尿病と糖尿病の鑑別並びに糖尿病における本唷の適否決定に応用佂值ありと考える。

私達の成績は図 1 亿示す如く, 糖尿病ではD860塣射30分後の血糖減少率が25\%より少く，120分後では反

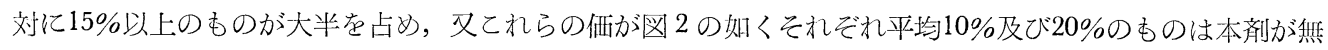
效であつた。

D860 負荷前の血糖做についてふると，D860 有效群では平均 $208 \mathrm{mg} / \mathrm{dl}$ で無効群の平均 $269 \mathrm{mg} / \mathrm{dl}$ 亿 比心低値である。乙れは20才以後に発病した煻尿病では D860 亿 responsive 加否加は空腹時血糖值の多少 が関係すると云う Mirsky ${ }^{8)}$ の説に一致し, 又 Wrenshall \& Best ${ }^{9)}$ む述べる如く本剂の血糖降下作用に endogenous Insulin の量が関連するととを示するのと云えよう。

又 D860 注射 2 時間後の血糖は D860 有效群では正常值に近接し，平均 $123 \mathrm{mg} / \mathrm{dl}$ となり，上述の Joslin 
らの判定基準の価とほぼ一致した。

インシュリン感性については図 3 亿示す如くD 860 有効群の加無効群より血糖减少が著しく（但し有効 群では 1 時間後より柽度の恢復を示す)，D860 Response Test の血糖曲線之近似であつた。しかしての所

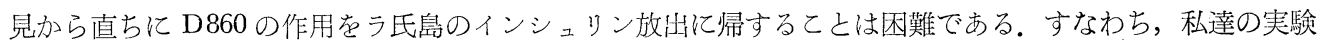
成績に示す如く D860 注射後の血糖降下の発現時間がインシュリン注射の際と等しいととや, 教室神出 ${ }^{15}$ の 犬実験における肝よりの糖放出又は血中ピルビン酸の消長が D 860 とインシュリンでは異るととなどを併せ 考えると本剤の作用機序には膵よりのインシニリン放出のみならず他の因子あ関与するととを考慮しなけれ ばならないであろう。

なお副作用としては注射局所の一過性の血管痛を訴えたもの, 或は柽度の低血糖症状を 1 ～ 2 の症例にお いて認めた他は特別のすのはなかつた。

\section{結語}

（1）D860 500 mg を静注すると，30分後の血糖減少率は正常人では壮均43\%，糖尿病慁者のD860有効群 で注平均 $23 \%$ ，無效群は平均10\%であつた。

（2）D860 静注後の血糖曲線は正常人では30分後に最低となり，2 時間後に前值に恢復したが，糖尿病で 注血糖下降が徐々で 2 時間後も減少を続けた。

(3) このように D 860 静注後 30 分及び 120 分の血糖を検するととにより糖尿病と非糖尿病を鑑別し，又糖 尿病患者におけるD860 治療の適否判定に応用するととが出来る。

（4）D860 注射後の血糖減少率が大なるものはインシュリンによる血糖下降も著しく，雨者は近似の血糖 曲線を示した。乙れは D 860 がラ氏島よりインシュリンを放出するととを示唆するが，本剤の作用機序につ いては他の因子も併せ考慮しなければならないと考える。

（附記 D860 注射液は小野楽品工業 $\mathrm{KK}$ の好意によ勾提供志うけた）。

\section{文献}

1) Joslin, E.P. : Treatment of Diabetes Mellitus, 10 Edition, Phyladelphia, Lea \& Febiger, 306 (1959)

2) Unger R.H. et al. : Diabetes, 7(6), 455 (1958)

3) 塩滂他：日内誌，46(9)，1200 (1957)

4) 塩津他：臨牀内科小児科，13(6)，561 (1958)

5) Pfeiffer, E.F. : J. Endocrinol., 15, XL VII (1957)

6) Camerini-Davalos, R. et al. : Metabolism. 5(6), 904 (1956)

7) Pfeiffer, E.F. et al. : Dtsch. Med. Wschf. 82, 36, 1544 (1957)

8) Mirsky, J.A. et al. : Metabolism, 5(6), 875 (1956)

9) Wrenshal, G.A. \& Best, C.H. : Canad. M.A.J. 74, 968 (1956) 10) Pfeiffer, E.F. et al. : Dtsch. Med. Wschf. 82, 36, 1568 (1957) $\quad$ 11) Bravermann, A.E. et al.: Metabolism, 5(6), 911 (1956)

12) Unger, R.H. et al. : Diabetes, 7(6), 455 (1958) 13) Kinsell, L.W. et al. : Metabolism, 5(6), 864 (1956) 14) Mehnert, H. et al. : Arzneimittel Forschung, Heft 7A, 435 (1958) 15) 神 出: 京都府立医科大学誌，56(1), 109 (1959) 